\title{
Role of Chlamydia in the Development of Ocular Adnexal Lymphoma
}

\author{
Carlo Contini $^{{ }^{*}}$, Silva Seraceni ${ }^{1}$, Martina Maritati $^{1}$, Francesco Cavazzini ${ }^{2}$, Paolo Perri ${ }^{3}$ \\ ${ }^{1}$ Department of Medical Sciences, Section of Infectious Diseases, University S. Anna Hospital, Ferrara, Italy; ${ }^{2}$ Department of Bio- \\ medical Sciences, Section of Hematology, University S. Anna Hospital, Ferrara, Italy; ${ }^{3}$ Department of Biomedical Sciences and Spe- \\ cialistic Surgery, Section of Ophthalmology, University of Ferrara, Ferrara, Italy. \\ Email: *cnc@unife.it
}

Received February $21^{\text {st }}, 2013$; revised March $23^{\text {rd }}, 2013$; accepted March $30^{\text {th }}, 2013$

Copyright (C) 2013 Carlo Contini et al. This is an open access article distributed under the Creative Commons Attribution License, which permits unrestricted use, distribution, and reproduction in any medium, provided the original work is properly cited.

\begin{abstract}
The aetiology of OAL is undefined, although much attention has been recently focused on determining whether OAL is caused by an autoimmune disorder, chronic antigenic stimulation or both. It is becoming evident that infectious agents underlying chronic eye infection, as Chlamydia, may play a role in ocular lymphomagenesis. The high prevalence of Chlamydophila psittaci in patients with OAL has suggested a potential oncogenic role for its tendency to cause chronic and persistent infections, although it has been documented an evident geographical variability and response to antibiotic treatment. For C. pneumoniae, the findings so far obtained are very limited not only for identification in OAL but also for the specific treatment with antibiotics. The recent molecular and cultural evidence of $C$. trachomatis in patients with $\mathrm{OAL}$, seems to suggest that also this pathogen may contribute to pathogenesis of such lymphoma. The potential application of bacteria-eradicating therapy at local and systemic level may ultimately result in safer and more efficient therapeutic option for patients affected by these malignancies. Moreover, a close collaboration between experts in ophthalmology, infectious diseases and hematology will help, in the future, to effectively manage this disease. This review attempts to weigh the currently available evidence regarding the role that Chlamydia play in development of OAL and focuses on patients with OAL observed at our Institution.
\end{abstract}

Keywords: Ocular Adnexa Lymphoma; Chlamydia; PCR; Antibiotic; Doxycycline

\section{Introduction}

Non-Hodgkin's lymphomas represent the most common ocular adnexa neoplasms and approximately account for $5 \%-15 \%$ of all extranodalmarginal zone (MZ) lymphomas, localizing at the conjunctiva, orbital soft tissue and lachrymal apparatus of the ocular adnexa [1-2]. Extranodal MZ B-cell lymphomas of mucosa-associated lymphoid tissue (MALT lymphomas) are the second most common indolent lymphomas among all non-Hodgkin lymphomas and originate from B cells of the MZ of MALT [2].

MALT lymphomas arise in lymphoid tissue acquired in certain extranodal sites as a result of chronic inflamemation or autoimmune disorders. In particular, the chronic antigenic stimulation and the action of infectious oncogenes somehow related to these agents (bacterial or viral) have been suggested to evoke host immune re-

${ }^{*}$ Corresponding author. sponses and to promote and sustain clonal B-cell expansion [3].

In this context, for certain species of bacteria oncogenic properties have been demonstrated. Helicobacter pylori infection has shown to cause gastric cancer, chronic carriers of Salmonella typhi are at more risk of developing gallbladder or hepatobiliary carcinoma than noncarriers, Mycoplasma like organisms have been suggested to be associated with Hodgkin's disease and Borrelia burgdoferi in cutaneous B cell lymphoma [4-7]. Moreover, many bacteria that cause persistent infections produce toxins that disrupt cellular signaling, alter the regulation of cell growth, induce inflammation or directly damage DNA.

The aetiology of ocular adnexa lymphoma (OAL) is currently unclear, even though it is becoming more and more evident that infectious agents underlying chronic eye infection, as Chlamydia, herpes simplex and adenovirus may play a role in ocular lymphomagenesis $[2,8]$. 
One of the bacterial agents which in recent years has gained attention is the bacterium Chlamydia psittaci implicated as potentially oncogenic for its tendency to cause chronic and persistent infections [8-10].

This review attempts to weigh the currently available evidence regarding the role that Chlamydia plays in development of OAL and focuses on patients with OAL observed at the Department of Infectious Diseases of University of Ferrara.

\section{Epidemiologic, Clinical and Cytogenetic Features of OAL}

Lymphomas of the ocular adnexa are a heterogeneous group of lymphomas that account for approximately $1 \%$ to $2 \%$ of all NHL and approximately $7 \%$ to $8 \%$ of extranodal lymphomas [11-13].

OAL comprise both primary extranodal lymphomas, which constitute the majority of cases, and secondary tumors in patients with systemic lymphoma [14]. Extranodal marginal zone lymphoma of MALT type is the most common histologic subtype of primary OAL, constituting about $35 \%$ to $80 \%$ of cases [15].

In Western countries marginal zone B-cell lymphoma of MALT-type accounts $50 \%-78 \%$ of all OAL, while in Japan and Korea the frequency rate is much higher especially in younger patients [16].

The incidence of OAL has increased by $6.3 \%$ annually in the period from 1975 to 2001, more rapidly than nonHodgkin lymphomas at other extranodal sites [17]. Overall, although relative rare lymphoproliferative disorders, recent studies suggest a possible increase in the incidence of MALT lymphoma in the last decade [18].

OALs are mostly seen in the fifth to seventh decade of life [median age, 65 years], with a female predominance and the majority $(85 \%-90 \%)$ of patients present with localized disease (Stage I). They can infiltrate every orbital and ocular adnexal tissue [19]. The slow evolution of symptoms, especially in conjunctival lymphomas explains the long median interval between onset of symptoms and time of diagnosis ranging from 1 month to 10 years (median, 7 months). One of the main reasons of the slow evolution may lie in the lack of connective tissue stroma of neoplastic lymphocyte population which is able to model surrounding tissue without causing particular irritation.

The most frequent site of origin is the orbit $(40 \%)$, followed by conjunctiva [35\% - 40\%], lachrymal gland $(10 \%-15 \%)$, and eyelid (10\%) [19,20]. Most patients with conjunctival lymphoma have visible, characteristic "salmon-pink patch" lesions reflecting tumour vascularity associated with swollen conjunctiva, redness and irritation (Figure 1). Lack of symptoms is also possible in a large number of cases.

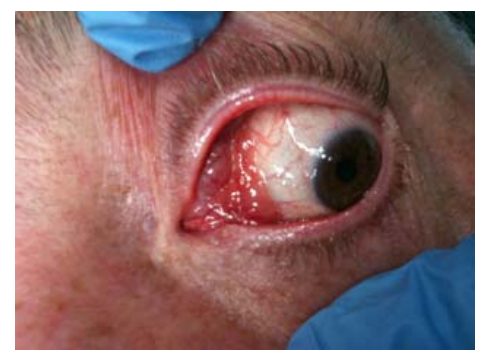

Figure 1. Representative conjunctival lymphoma of MALTtype with typical salmon colour appearance with diffuse margins and swollen conjunctiva.

Intraorbital lymphoma most frequently presents with painless diffuse ill-defined or circumscribed mass that may be associated with exophthalmos, proptosis, epiphora, dacryocystitis, diplopia or motility disturbance, gritty sensation. Only a few patients, primarily with orbital lymphoma, complain of pain or irritation [21-23]. Swelling may be one of the predominant symptoms for lymphoma arising in the lachrymal sac. These are often non-specific, and might be misdiagnosed as chronic dacryocystitis with nasolacrimal duct obstruction.

MALT lymphoma may also be associated with chronic conjunctivitis, resembling what happens for gastric MALT lymphoma, which is associated with $H$. pylori derived chronic gastritis.

In OAL, a B-cell clonal expansion and proliferation has been supposed by the presence of somatically hypermutated immunoglobulin genes with an ongoing mutations pattern [24]. Chronic antigenic stimulation may induce genetic instability with subsequent chromosomal abnormalities, which, associated with the microenvironment, can make the process of clonal growth independent from antigenic stimulation.

Microscopically neoplastic cells are monocytoid, centrocytic-like or lymphoplasmocitoid [24]. OAML are characterized by prevalence of one of mentioned cell types [25]. Immunoprofile is similar to other MALT lymphoma, being neoplastic cells $\mathrm{CD} 20^{+}, \mathrm{CD} 7 \mathrm{a}^{+}, \mathrm{CD}^{-}$, $\mathrm{CD}^{-}, \mathrm{CD} 10^{-}$, bcl- $6^{-}, \mathrm{IgM}^{+}, \mathrm{bcl}-2^{+}, \mathrm{CD} 43^{+/-}, \mathrm{CD} 23^{-1+}$, $\mathrm{CD} 21^{+/-}, \mathrm{TCL1}^{+}, \mathrm{PAX}^{+}, \mathrm{CD} 11 \mathrm{c}^{+/-}, \mathrm{CD} 35^{+/-}$, and $\mathrm{IgD}^{-}$, cyclin $\mathrm{D}^{-}$, $\mathrm{MUM1}^{-}$[19]. Differential diagnosis of OAML is generally with other small cells lymphomas, such as mantle cell lymphoma, follicular lymphoma and small lymphocytic lymphoma and with reactive lymphoproliferative disorders.

Several structural chromosomal abnormalities have been demonstrated in MALT lymphoma. Their frequency varies with the anatomic site of the lymphoma [26]. These include $\mathrm{t}[14 ; 18]$ [q32; 21$]$ involving IGH and MALT1, t[11;18] [q21;q21] involving API2 and MALT1, $\mathrm{t}[1 ; 14]$ [p22;q32] involving Bcl-10 and IGH, and t[3;14] [p14;q32] involving FOXP1 and IGH [27]. All of these, except the translocation involving FOXP1, lead to for- 
mation or up-regulation of proteins (API2-MALT1, MALT1 and bcl-10) that ultimately target the NF- $\kappa$ BA20 gene by stimulating cell proliferation and survival $[28$, 29].

Recently, homozygous deletions of a negative regulator of NF- $\kappa \mathrm{B}$ A20 gene, were described in OALs, suggesting a role for this gene as a tumor suppressor in this disease [30].

So far, the aetiology of OAL is undefined, although much attention has been focused on determining whether OAL is caused by an autoimmune disorder, chronic antigenic stimulation or both.

The chronic antigenic stimulation hypothesis claims that a specific infectious agent initiates a reactive lymphoid infiltrate in the normally sterile ocular adnexal tissues and leads to a B-cell clonal expansion and proliferation. At this stage, genetic alterations and microenvironment may sustain an independent growth of the infectious agent. The most common genetic abnormalities reported in OALs of MALT type are trisomy of chromosome 3 and chromosome 18 in up to $68 \%$ and $57 \%$ of patients, respectively [31].

It is now becoming evident that infectious agents underlying chronic eye infection, as Chlamydia, herpes simplex and adenovirus may play a role in ocular lymphoma genesis in certain geographic regions. In general, $C$. psittaci and $H$. pylori may contribute to the pathogenesis of conjunctival MALT lymphoma, whereas Chlamydiae (C. psittaci and C. pneumoniae) and HCV can be considered the putative organisms that may play a role in the etiology of orbital MALT lymphoma [20].

In the past few years several studies have reported increasingly the possible role of Chlamydiae in the development of OAL. Although the large number of papers reported in the literature concern with C. psittaci, there is evidence that other Chlamydiae such as $C$. trachomatis and C. pneumoniae can somehow be implicated in the pathogenesis of OAL.

\section{Chlamydia Morphology and Function}

The Chlamydiae are ubiquitous gram negative, aerobic, obligate intracellular bacteria which grow in eukaryotic cells and are responsible for wide range of human diseases.

In 1999, Everett proposed a new taxonomic classification to rename some Chlamydiaceae including C. pneumoniae and C. psittaci in Chlamydophila pneumoniae and Chlamydophila psittaci [32]. The revised taxonomic classification currently contains at least 4 distinct families (Chlamydiaceae, Simkaniaceae, Parachlamy diaceae and Waddliaceae) based on $>90 \% 16 \mathrm{~S}$ rRNA identity and acommon developmental cycle.

Chlamydiae, have a unique life cycle largely responsible for the molecular pathogenesis of chronic chlamydial infections in human disease. The life cycle for Chlamydia species begins with the elementary body (EB, 0.3 $0.6 \mathrm{~m}$ diameter), an infectious, metabolically inert "sporelike" form that is able to attach to a target host cell and stimulate uptake by this host cell. For C. pneumoniae, airborne infectious EBs produced through coughing by infected persons, is the manner in which this infection is transmitted from one person to another.

The discovery that EBs can translocate stored proteins into the host under distinct signaling pathways is further evidence that the entry process results from a dialogue between the bacteria and the host, although many features including EB protein attachment to target cells remain to be clarified or discovered $[33,34]$.

After attachment to and internalization within the host cell, the EB transforms into a non-infective, metabolically active form called a reticulate body (RB, $0.6-1 \mathrm{~m}$ diameter) that replicate by binary fission within a hostderived vacuole called an inclusion body [35]. During the replication process, some of the RBs transform back to EBs in an asynchronous manner. This orderly alternation between $\mathrm{EB}$ and $\mathrm{RB}$ in life cycle development usually takes place in $72 \mathrm{~h}$, ranging from 36 to $96 \mathrm{~h}$ to complete, depending on each species. Under in vitro conditions, RBs block division and maintain a stable association with the infected cell and become the "aberrant" or persistent bodies with enlarged forms, altered gene expression profile and multiple nucleoids instead of undergoing rapid replication and differentiating into infectious EBs. During persistent growth, aberrant RBs continue chromosome replication but fail to divide [36]. These events constitute the basis of clinical persistence leading to chronic sequelae.

This replicative life cycle is characteristic of acute chlamydial infection. More recently a shift in this biphasic paradigm $[37,38]$ has occurred with the identification of a no replicative persistent intracellular form of chlamydiae; this cryptic form characterized by an altered gene expression as well as ultrastructural changes [39], is now recognized as causing chronic chlamydial infections.

\section{Pathogenesis of Chlamydia Persistence and Chronic Infection}

Persistence has long been recognized as a major factor in the pathogenesis of Chlamydia disease. It has been described as a viable but non-cultivable growth stage resulting in a long-term relationship with the infected host cell that may not necessarily manifest as clinically recognizable disease. It differs from unapparent infections, which may or may not involve evident Chlamydia growth and refers to an atypical, intracellular and metabolically less active state that is difficult to resolve not only by the host-defence system, but also by antibiotic therapy. 
Unlike the re-infections believed to be the result of exposure to a Chlamydia serotype different from the initial, persistent infections are due to the same type of pathogen genotype entered into a metabolic quiescent and non-infectious form and responsible of three to ten recurrences which can last many years [40].

In vitro studies have shown that several factors including nutrient depletion, cytokines (INF- $\gamma$ ), iron restriction, amino acids, $\mathrm{Ca}++$, and certain antibiotics can induce the Chlamydial persistent stage $[9,41,42]$. In particular IFN- $\gamma$ directly inhibits bacterial growth [43] and induces Chlamydia persistence by allowing 60 and 12 $\mathrm{kDa}$ cystein protein inhibition and tryptophan depletion which can stop the expression of late proteins such as major outer membrane protein (MOMP) that in turn stop the progress of $\mathrm{RB}$ division and $\mathrm{RB}$ conversion into $\mathrm{EBs}$ leading to aberrant Chlamydial RBs $[41,44]$.

During Chlamydia invasion and intracellular growth, sensors of the host innate immunity (pattern recognition receptors, PRR) can detect the infection by recognizing microbial components (pathogen associated molecular patterns, PAMPs). Chlamydia PAMPs such as Hsp-60 and Macrophage Infectivity Potentiator lipoprotein (MIP) are recognized by host PRR TLR4 and TLR2 respectively. These host receptors selectively recognize a broad spectrum of microbial components and endogenous molecules released by injured tissue [45]. In particular, TLR4 and TLR2 have been reported to be essential mediators of $C$. pneumoniae related host cell activation and defense and MyD88, the central TLR signaling adaptor molecule during Chlamydial infections, is crucial for the initiation of effective host defenses induced by recognition of C. pneumoniae by TLRs [46]. During C. pneumoniae respiratory infection, it is likely that both TLR2 and TLR4 signaling via MyD88 induce early cytokine and chemokine production and control infection.

MIP or other lipoproteins could be released from EB surface and RBs, and retain inside tissues where they might activate resident cells and perpetuate inflammatory response even after the eradication of live bacteria with antibiotic therapy [45]. In general, PRRs, upon ligand binding, can lead to activation of various inflammatory signaling pathways including NF- $\kappa \mathrm{B}$, NF-IL-6 and MAP kinases.

Type III secretion (T3S) apparatus is another mechanism which seems central to the biology of the Chlamydiaceae, as it mediates, as occurs in several important gram-negative bacterial pathogens, the translocation of bacterial toxins to the cytosol of infected cells [47]. It consists a molecular injection system protruding from the outer membrane that appears to be expressed and functional in acute as well as in chronic infection and may represent a prominent virulence factor. A major role of T3S may also involve, ensuring growth and development of the pathogen by modifying apoptosis signals or some other transcriptional regulation important for Chlamydia survival. Chlamydial protease or proteasome-like activity factor (CPAF) has been also proposed to be a major virulence factor in Chlamydia infected cells [48]. During an infection, CPAF is secreted into the host cytoplasm where it has been reported to cleave or degrade specific host proteins. This conserved chlamydial protease is likely to play an important role during the intracellular chlamydial infection.

\section{Chlamydiae Spp. and Their Role in Chronic Diseases and in Cancer}

Chronic infection and clinical persistence are closely related. Inhibition of apoptosis which could otherwise be used as a host defense mechanism against this intracellular pathogen, could represent a mechanism that has evolved to establish a chronic infection.

In general, all different species of Chlamydia have tendency to cause persistent infections that may play a role in chronic diseases (inflammation and scarring with significant damage to the host and oncogenesis).

C. trachomatis other to cause chronic, clinically unapparent infections of the upper genital tract that may result in significant damage to the reproductive organs [49], can cause cervical dysplasia and cancer [50] including ovarian cancer [51] and can also lead to vulvar carcinogenesis [52]. Importantly, C. trachomatis has been shown to be fully viable and metabolically active in both the acute and chronic, persistent infection.

Several lines of evidence suggest that to provoke chronic infection, C. trachomatis could adopt several strategies. One of these consists of being silent, resulting in asymptomatic infections that cannot be diagnosed at that time. This promotes bacterial progression, even to the most internal tissues. In addition, $C$. trachomatis MOMP displays variable immunodominant antigenic epitopes. Variations in these epitopes explain the absence of strain specific immunity and multiple re-infections by different serovars or by the same mutated serovar are still possible [53]. For these reasons, even if the initial infection is resolved, re-infections are possible and can lead to autopathological immune response induction [41]. Previous studies have also revealed that in C. trachomatis infection, the cytosolic levels of Hsp-60 in vivo gradually increase during carcinogenetic steps, from normal tissue to dysplasia to fully developed carcinoma in various organs [54].

C. pneumoniae is a widespread pathogen, a common cause of pulmonary infection, with serum positivity in at least $50 \%$ of the general population [55].

A chronic C. pneumoniae infection increases the expression of its own Hsp-60 which continuously stimulates the host immune cells to produce anti-Hsp-60 anti- 
bodies inside but also outside cells. Thus, the immune response to microbial Hsp-60 may gradually lead or contribute to autoimmunity to host self antigens and conesquently, to the development of chronic diseases such as asthma, stroke, degenerative joint diseases, atherosclerosis, coronary heart disease, multiple sclerosis [56-61] or favor the onset of cancer [62] or lymphoma. Chronic infections by $C$. pneumoniae are associated with small and squamous lung cancer and cutaneous T-cell lymphoma [63]. Persons with elevated anti C. pneumoniae IgA antibody titers have up to a twofold increased risk for small cell carcinomas and adenocarcinomas of the lung and it is increased in male smoker patients with chronic C. pneumoniae infection [63-64]. Moreover, a significant association has been found with elevated Chlamydia Hsp-60 seropositivity, thus supporting an etiologic role of $C$. pneumoniae in lung carcinogenesis $[62,65]$.

C. pneumoniae is also potent inducer of the proinflammatory cytokines TNF-a , IL-1b, and IL-6 in human monocytic cells, which may contribute to cancer development as demonstrated by the ability to activate PBMCs in vitro, and to grow inside these cells [66]. In this context, during or after respiratory infections, the chronically infected PBMC, capable of internalizing C. pneumoniae, but unable to kill this organism, appear to migrate transendothelially and to either transmit their infectious load to other cell types, disseminating and causing infection in distant tissues, including veins, or to remain as an infected focus in the arterial wall.

Monocytes and macrophages are known to be carriers of the infection from the respiratory site to other sites in the body and cause both local and systemic infection [67]. In fact, as happens in various chronic diseases, C. pneumoniae may be transported by infected monocytes and participate in the maintenance of local immunological response and inflammation, delaying its clearance $[61,68]$.

The replication of this pathogen within lymphocytes suggest that these cells may be an important host cell for dissemination of organisms and may alter lymphocyte functions and certain immune mechanisms in infected individuals [69]. A role of the neutrophil as a "Trojan horse" has recently been recognized as an infection-promoting factor [70].

C. pneumoniae can thus survive in different immune cells, and use these as carriers for potentially cause chronic/persistent infections due to host inability for complete elimination of the pathogen [71].

Infections by $C$. psittaci are predominantly associated with chronic conjunctivitis. However, a strong relationship between C. psittaci and its potential carcinogenic role in OAL of MALT type development has been established [8] owing in part to their mitogenic in vitro activity $[72,73]$, in vivo polyclonal lymph proliferation and resistance to apoptosis in infected cells $[74,75]$.

Besides OAL, C. psittaci infection was associated with non gastrointestinal MALT lymphomas [lung, thyroid and salivary gland, skin] and autoimmune precursor lesions (Hashimoto thyroiditis and Sjogren syndrome), suggesting possible involvement of $C$. psittaci induced antigen driven MALT lymphoma genesis [76].

\section{The Role of Chlamydiae in the Development of OAL. Evidences and Controversies}

\subsection{Chlamydia psittaci}

C. psittaci is an obligate and intracellular gram negative bacterium with seven known genotypes (A-F and E/B) that can be transmitted to humans. C. psittaci [now reclassified as Chlamydophila psittaci), is the etiologic agent of psittacosis, a human infection caused by exposure to a consistent number of infected birds. Additionally, C. psittaci has been isolated in secretions of infected cats with upper respiratory tract infections of seasonal conjunctivitis, thus being an additional source of human infections [77].

The association of OAL with $C$. psittaci has been reported mostly in subjects coming from rural areas, following a prolonged contact with household animals [8]. C. psittaci DNA was detected by PCR in ocular lesions from most of patients with OAL but not in controls [8]. Specific bacterial DNA was also found in PBMCs from patients with OALs. In some cases, PBMC samples were positive for $C$. psittaci DNA more than 5 years after lymphoma diagnosis, with a concurrent relapse of the disease, suggesting that the natural history of OAL is associated with the persistence of the $C$. psittaci infection, due to chronic antigenic stimulation and further supporting an etiologic role of this bacterium [78]. Specific antibiotic therapy with tetracycline using standard dosing regimens for 21 days eradicated (although often incompletely) the ocular disease. This therapeutic approach has revealed to be fast, cheap and well tolerated for treating OALs even for aged and heavily pretreated patients with conventional more aggressive therapy $[8,79]$.

The assessment of $C$. psittaci DNA in patient's PBMCs was thus considered apotential and useful tool to evaluate disease eradication and even detect reinfectionor reactivation. The genotypic and phenotypic differences among the strains of the pathogen should also be taken into account while performing this assessment [80].

C. psittaci elementary bodies in the PBMCs were found viable and infectious and capable to grow in vitro and to be isolated from patients with OAMZL [79]. Taken together, the fact that $C$. psittaci can be isolated and grown in vitro from biological samples of OAL patients, improves the evidence level supporting this bacte- 
ria-lymphoma association and fulfills the second Koch's postulate hitherto reserved for $H$. pylori for gastric lymphoma [81].

Other evidences suggesting the potential implication of $C$. psittaci in OAL come from Yoo [82] who found a high correlation between $C$. psittaci and OAL in Korean patients with a detection rate of bacteria DNA in about $80 \%$ and from Aigelsreiter [76] who detected C. psittaci DNA in 53.8\% of MALT lymphomas from Austrian patients. These evidences strengthen that $C$. psittaci and bacterium driven antigens may have a causal role in the development of OALs and in sustaining the disease overtime, although often clinically unapparent.

The strong association of $C$. psittaci with ocular adnexal lymphomas, observed by Ferreriwas not be confirmed by other groups, $[10,19,24,31,83-85]$ suggesting evidence for geographic heterogeneity.

In Italy and Korea the prevalence of the microorganism is greater than $75 \%$, in others like Germany, Netherlands, UK, China, Eastern US and Cuba, the prevalence is included between $10 \%$ and $50 \%$, other countries such as France, Japan etc. have a prevalence below $10 \%$ [10, $19,31,86,87]$. In Kenya, where the underdeveloped conditions and the rather high plethora of infectious agents which could establish an excellent pabulum for the cancerous transformation and the development of the OAL, no association has been found between OAL and C. psittaci [88].

The possibility that $C$. psittaci may be variably associated with OAL in various geographic regions, the genetic background of different populations, the varying epidemiological risk factors among different geographic areas, the fact that $C$. psittaci plays a causative role only in some OAL patients, may affect the incidence of these lymphomas.

Overall, these findings suggest that the variability of the prevalence rated worldwide may be affected not only by geographical differences but also by the different sensitivity of the methods used for sample collection, PCR analysis and sequence diversity in the target region of $C$. psittaci $[66,89,90]$.

A large study involving an adequate number of cases from several countries andconducted with the same methodological diagnostic approach in order to exclude-falsepositive results, would be, although utopian for the moment, desirable.

In this context, however, the touchdown enzymetimerelease polymerase chain reaction (TETR-PCR) based technique designed to simultaneously detect Chlamydia DNA, proved to be the best method for the molecular detection of $C$. psittaci DNA and able to discriminate between $C$. psittaci and C. pneumoniae $[8,91,92]$.

TETR PCR technique simultaneously detects $C$. pneumoniae, C. psittaci and C. trachomatis DNA at bacterial load lower than one Inclusion Forming Unit. The DNA fragment amplified with this protocol includes the end of the 16S rRNA gene and the beginning of the 16S-23S spacer region. PCR products are then analyzed by electrophoresis and DNA fragment size is quantified by image analysis. The specificity of the amplified DNA is confirmed by sequencing to verify the degree of homology between the genomic regions among Chlamydial species and to exclude false positivity. Several other PCR methods have been recently proposed.

In Table 1 are shown the different techniques employed to assess Chlamydia $S p$. prevalence in clinical samples from patients with OAL. These techniques have detected C. psittaci in a consistent number of OALs suggesting the possible contribution of this bacterium in lymphoma development and the possible adoption of antibiotic therapy.

\subsection{C. pneumoniae}

There are few reports describing the association of $C$. pneumoniae with MALT lymphomas but with conflicting results $[93,94]$ and C. pneumoniae DNA has been detected in a few cases of OAML. Its seroprevalence is a relatively high [ranging from $40 \%$ to $90 \%$ ] in some geographic areas, including Japan, Taiwan, and Hong Kong and it is probably related to the genotypic and phenotypic differences among the strains of the pathogen [80]. Molecular identification could represent an interesting approach for the diagnosis of Chlamydia infections, especially for C. pneumoniae.

\subsection{C. trachomatis}

C. trachomatis is an obligate intracellular gram negative bacterium which was first identified as the etiologic agent in blinding trachoma in Africa and the Middle East and later was demonstrated to be a genital pathogen of widespread occurrence in both developed and under developed areas of the world. Indeed this organism is now considered to be the most common sexually transmitted bacterial pathogen in the United States, with more than a million new such infections reported annually to the Centers for Disease Control [95].

Significantly, primary genital infection with this organism often engenders severe sequelae, including fertility problems in women, arthritis in both genders, and others $[96,97]$. Current data indicate that these sequelae involve organisms in an unusual state designated persistence, in which metabolic and genetic activity are modified to yield a largely antimicrobial-refractory organism [97,98].

The possible involvement of $C$. trachomatis in the development of OAL seems not supported by strong evidence of the literature. The MEDLINE and PubMed da- 
Table 1. Molecular techniques employed for the detection of Chlamydia spp. in clinical specimens from OAL patients.

\begin{tabular}{|c|c|c|c|c|}
\hline Specimen type & Molecular technique and gene target & $\begin{array}{l}\text { Positive patients } \\
\text { (n/\%) }\end{array}$ & $\begin{array}{l}\text { Chlamydia } \\
\text { spp. }\end{array}$ & Reference \\
\hline $\begin{array}{l}\text { Biopsy tissue (formalin-fixed, } \\
\text { paraffin-embedded) }\end{array}$ & TETR-PCR & $9 / 100$ & C. psittaci & $\begin{array}{l}{[10,78,80,82,} \\
\quad 93,94]\end{array}$ \\
\hline PBMC & $\begin{array}{l}\text { 16S rRNA and } 16 \mathrm{~S}-23 \mathrm{~S} \text { spacer region } \\
\text { (C. psittaci } 111 \mathrm{bp})\end{array}$ & $0 /-$ & C. psittaci & \\
\hline $\begin{array}{l}\text { Microdissected tumor cells from } \\
\text { formalin-fixed, paraffin-embedded tissue }\end{array}$ & & $1 / 12.5$ & C. pneumoniae & \\
\hline \multirow[t]{6}{*}{ biopsy tissue } & & $1 / 100$ & C. pneumoniae & \\
\hline & & $26 / 78$ & C. psittaci & \\
\hline & & $3 / 9$ & C. pneumoniae & \\
\hline & & $0 /-$ & C. trachomatis & \\
\hline & & $92 / 23$ & C.pssittaci & \\
\hline & & $6 / 100$ & C. psittaci & \\
\hline $\begin{array}{l}\text { Biopsy tissue (formalin-fixed, } \\
\text { paraffin-embedded) }\end{array}$ & Multiplex (TETR-PCR) & $32 / 80$ & C. psittaci & $\begin{array}{l}{[8,84,86,88} \\
109]\end{array}$ \\
\hline \multirow[t]{5}{*}{ PBMC } & Sequencing & $0 /-$ & C. psittaci & \\
\hline & Southern blot & $31 / 22$ & C. psittaci & \\
\hline & FISH & $11 / 41$ & C. psittaci & \\
\hline & $\begin{array}{l}\text { 16S rRNA and 16S-23S spacer region (C. psittaci } 111 \\
\text { bp, C. pneumoniae } 197 \mathrm{bp}, \text { C. trachomatis } 315 \mathrm{bp})\end{array}$ & $0 /-$, African pat. & C. psittaci & \\
\hline & $\begin{array}{l}\text { 16S rRNA (C. pneumoniae } 73 \mathrm{bp} \\
\text { C. trachomatis } 116 \mathrm{bp})\end{array}$ & $5 / 17$, Italian pat & C. psittaci & \\
\hline \multirow[t]{5}{*}{$\begin{array}{l}\text { Biopsy tissue (formalin-fixed, } \\
\text { paraffin-embedded) }\end{array}$} & TETR-PCR & $0 /-$ & C. psittaci & {$[85,110]$} \\
\hline & Real time PCR & $0 /-$ & C. psittaci & \\
\hline & 16S rRNA and 16S-23S spacer & & & \\
\hline & OmpA & & & \\
\hline & 16S rRNA & & & \\
\hline \multirow[t]{6}{*}{$\begin{array}{l}\text { Biopsy tissue (frozen or formalin-fixed, } \\
\text { paraffin-embedded) }\end{array}$} & TETR-PCR & $0 /-$ & C. psittaci & {$[83]$} \\
\hline & n-PCR & & & \\
\hline & PCR & & & \\
\hline & $\begin{array}{l}\text { 16S rRNA and } 16 \mathrm{~S}-23 \mathrm{~S} \text { spacer region } \\
\text { (C. psittaci } 111 \mathrm{bp})\end{array}$ & & & \\
\hline & 16S rRNA (C. psittaci 127 bp) & & & \\
\hline & OmpA (C. psittaci 248 bp) & & & \\
\hline \multirow[t]{8}{*}{ Biopsy tissue (fresh and frozen) } & PCR & $0 /-$ & C. psittaci & {$[110]$} \\
\hline & ALH-PCR & & & \\
\hline & TETR-PCR & & & \\
\hline & Cloning & & & \\
\hline & Sequencing & & & \\
\hline & $\begin{array}{l}\text { RNA/V1-V2 hypervariable region } \\
\text { (1400 and 312-314 bp) }\end{array}$ & & & \\
\hline & ITS & & & \\
\hline & $\begin{array}{l}\text { 16S rRNA and 16S-23S spacer region } \\
\text { (C. psittaci } 111 \mathrm{bp})\end{array}$ & & & \\
\hline $\begin{array}{l}\text { Biopsy tissue (formalin-fixed, } \\
\text { paraffin-embedded) conjunctival swabs }\end{array}$ & TETR-PCR & $15 / 75$ & C. psittaci & [79] \\
\hline
\end{tabular}




\section{Continued}

PBMC (fresh and after culture in J774A.1 cells)

Biopsy tissue (formalin-fixed, paraffin-embedded)

Biopsy tissue PBMC

(all specimen fresh and after co-culture in Hep2 cells)

Biopsy tissue PBMC

(all specimen fresh and after co-culture in Hep2 cells)

Immunostainig

\section{PCR and RFLP}

Sequencing

16S rRNA and 16S-23S spacer region (C. psittaci 111 bp, C. pneumoniae 197 bp, C. trachomatis 315 bp)

16S rRNA gene of Chlamydiae ( $270 \mathrm{bp}$, C. psittaci 269 bp by RFLP with enzyme MseI)

Hsp60 (universal target 555 bp, C. psittaci 174 bp)

TETR-PCR

PCR

n-PCR

Sequencing

IHC, IFS, EM, laser-capture microdissection

16S rRNA and 16S-23S spacer region (C. psittaci 111 bp, C. pneumoniae 197 bp, C. trachomatis 315 bp)

Hsp60 (universal target 555 bp, C. psittaci 174 bp)

OmpA (C. psittaci 207 bp, C. pneumoniae 333 bp) n-PCR and RT-PCR

\section{TETR-PCR}

Sequencing

16S rRNA (C. pneumoniae $270 \mathrm{bp}$ ), $16 \mathrm{~s}$ rRNA ( $C$. psittaci 126 bp, C. pneumoniae 221 bp, C. trachomatis $412 \mathrm{bp})$

OmpA (C. pneumoniae 488 bp, C. psittaci 494 bp, C. trachomatis $527 \mathrm{bp}$ )

Hsp60 (C. trachomatis: ct110 114 bp, ct755 155 bp, ct604 $161 \mathrm{bp}$ )

16S rRNA and 16S-23S spacer region (C. psittaci 111 bp, C. pneumoniae $197 \mathrm{bp}$,

C. trachomatis $315 \mathrm{bp}$ )

n-PCR and RT-PCR

TETR-PCR

Sequencing

16S rRNA (C. pneumoniae $270 \mathrm{bp}$ ), $16 \mathrm{~s}$ rRNA ( $C$. psittaci 126 bp, C. pneumoniae 221 bp, C. trachomatis $412 \mathrm{bp}$ )

OmpA (C. pneumoniae 488 bp, C. psittaci 494 bp, C. trachomatis $527 \mathrm{bp}$ )

Hsp60 (C. trachomatis: ct110 114 bp, ct755 155 bp, ct604 $161 \mathrm{bp}$ )

16S rRNA and 16S-23S spacer region (C. psittaci 111 bp, C. pneumoniae 197 bp, C. trachomatis 315 bp) tabases were searched for publications regarding the association between $C$. trachomatis and OAL as well as the efficacy of antibiotics employed for the treatment of OAL. The literature search spanned the period between January 2004 and November 2012. Two only cases were found [66].

\section{Focus on OAL Cases Admitted at Our Institution}

From June 2009 to September 2012, 5 Italian immunocompetent patients (median age 67 years, range $58-83$ years; 4 males) from Emilia Romagna Region (Italy), 
with Marginal zone B-cell lymphoma of MALT-type of the ocular adnexa, were admitted at our department. Patients were firstly observed at Section of Ophthalmology and then diagnosed (histology) at Section of Hematology of the University of Ferrara. Molecular studies for Chlamydia and antibiotic therapy were undertaken at Department of Infectious Diseases from the same Institution. None of these patient reported contact with household animals. Only two had chronic conjunctivitis. All patients gave written informed consent. The main clinical and laboratory findings of these patients are shown in Table 2. Four (n. 1, 3 - 5) displayed the well-known classical histopathology and immunophenotype profile of most MALT lymphomas; one patient (n. 2) had a cutaneous anaplastic large-cell lymphoma, positive for CD3, $\mathrm{CD} 2$ and CD30, and negative for CD5, CD56, ALK and CD20, as determined by immunohistochemistry. Ophthalmic lymphoma was the first presenting symptom and all patients had involvement of the ocular region only (Stage I).

Chlamydiae were searched in fresh lymphoma tissue biopsy and in PBMCs isolated by density gradient from peripheral blood (Fycoll-paque plus, GE Healthcare Europe $\mathrm{GmbH}$, Milan, Italy). DNA and RNA were extracted as previously described [100] and assayed by a nested-PCR designed to simultaneously detect $C$. pneumoniae, C. psittaci and C. trachomatis. A fraction of PBMCs was instead centrifuged, suspended in RPMI 1640 medium (Gibco, Invitrogen, Carlsbad, CA) and co-cultured up to 144 hours with Hep-2 cell line (ATCC CCL-23), to increase the number of bacterial inclusions [60]. Cultured samples were then processed as done for fresh uncultured cells. Molecular analyses also included PCR after retro-transcription (RT-PCR), using primer sets targeting 16S rRNA, outer membrane protein (ompA/MOMP), and HsP-60 genomic regions of C. psittaci, C. pneumoniae, and C. trachomatis [60,99].

Amplification fragments corresponding to C. pneumoniae 16S rRNA gene, were found both in tumor tissue and in co-cultured PBMCs from there patients (Figure 2).

Amplicons were sequenced by ABI PRISM 377 DNA Sequencer (Applied Biosystems, The Netherlands) and compared with other Chlamydiaceae genes (BLAST program http://www.ncbi.nlm.nih.gov/BLAST, showing a strict homology with C. pneumoniae TW183 strain (AE009440.1, 99\%; E value: $<0.01$ ).

Due to the ocular localization and to the prominent angiogenic component of the lesion, for the patient n. 2, molecular analyses to detect HHV-8 were also performed. These revealed the presence of a productive infection by both pathogens in surgical biopsy and in PBMCs [100].

Owing to detection of active chlamydial infection (mRNA transcripts), this patient was given doxycycline (Bassa$\mathrm{do}^{\circledR}$, Pfizer, Italy), $100 \mathrm{mg}$ twice a day, for 4 weeks. This treatment was safe and well tolerated, and C. pneumoniae was no longer detectable in PBMCs after the conclusion of antibiotic treatment.

Of the two patients with C. pneumoniae DNA positiviity, one (n. 3, 81 years old) had been previously treated with antibiotic therapy with the same protocol. The achieved response monitored through PBMC evaluation for $C$. pneumoniae DNA was incomplete and lymphoma evolved. The patient was successfully treated with Rituximab (anti-CD20), cyclophosphamide, vincristine and prednisone, with reduction of the pathological tissue and general improvement.

The other patient (n. 4) was 72 years old with ocular lymphoma discovered in April 2008. Since August 2008

Table 2. Clinical, histologic, cytogenetic and microbiological characteristics of patients with OAL observed at our Institution.

\begin{tabular}{|c|c|c|c|c|c|}
\hline $\begin{array}{l}\text { Patient } \\
\text { number }\end{array}$ & Site of disease & Histology & $\begin{array}{c}\text { Lymphoma } \\
\text { immunophenotype }\end{array}$ & $\begin{array}{l}\text { Microbiological } \\
\text { findings }\end{array}$ & Response after antibiotics \\
\hline 1 & $\begin{array}{l}\text { Medial upper } \\
\text { orbit }\end{array}$ & B lymphocytic lymphoma & $\begin{array}{l}\mathrm{CD}^{2} 0^{+}, \mathrm{CD}^{-}, \mathrm{CD}^{-} \\
\text {Cyclin } \mathrm{D}^{+}\end{array}$ & Negative & $\begin{array}{l}\text { *Incomplete, } \\
\text { Lymphoma stable }\end{array}$ \\
\hline 2 & $\begin{array}{l}\text { Upper right } \\
\text { eyelid }\end{array}$ & $\begin{array}{l}\text { Cutaneous anaplastic } \\
\text { large-cell lymphoma }\end{array}$ & $\begin{array}{c}\mathrm{CD}^{-} 0^{+}, \mathrm{CD}^{+} \\
\mathrm{CD}^{-}, \mathrm{CD}^{-} 6^{-}, \mathrm{ALK}^{-}, \mathrm{CD} 20^{-}\end{array}$ & $\begin{array}{l}\text { C. pneumoniae, } \\
\text { HHV-8 }\end{array}$ & ${ }^{\circ}$ Complete \\
\hline 3 & $\begin{array}{l}\text { Upper front } \\
\text { right orbit }\end{array}$ & $\begin{array}{c}\text { B lymphocyte mantle cell } \\
\text { lymphoma }\end{array}$ & $\begin{array}{c}\mathrm{CD}^{+}, \mathrm{CD}^{2} 0^{+}, \mathrm{Cyclin}^{-} 1^{+} \\
\mathrm{CD}^{-}, \mathrm{CD} 23^{-}, \mathrm{CD} 138^{-} \\
\mathrm{BCL}^{-} 6^{-}\end{array}$ & C. pneumoniae & $\begin{array}{l}\text { Partial, then recurrence and } \\
\text { chemotherapy }\end{array}$ \\
\hline 4 & $\begin{array}{l}\text { Medial right } \\
\text { orbit }\end{array}$ & $\begin{array}{c}\text { B lymphocytic } \\
\text { linfoplasmocytic lymphoma }\end{array}$ & $\begin{array}{l}\mathrm{CD}^{2} 0^{+}, \mathrm{CD} 138^{+}, \mathrm{Cyclin}^{-} \\
\mathrm{IgM}^{+}, \mathrm{CD}^{-}, \mathrm{CD}^{-}\end{array}$ & C. pneumoniae & $\begin{array}{c}\text { Chemotherapy, lymphoma } \\
\text { progression, then } \\
\text { doxycycline }\end{array}$ \\
\hline 5 & $\begin{array}{c}\text { Bulbar } \\
\text { conjunctiva }\end{array}$ & $\begin{array}{c}\text { B lymphocytic } \\
\text { linfoplasmocytic lymphoma }\end{array}$ & $\begin{array}{l}\mathrm{CD} 20^{+}, \text {Cyclin D1 } \mathrm{IgM}^{+} \\
\mathrm{CD}^{-}, \mathrm{CD} 56^{-}\end{array}$ & C. trachomatis & $\begin{array}{l}{ }^{\wedge} \text { Chemotherapy, then } \\
\text { recurrence. }{ }^{\wedge} \text { Complete } \\
\text { remission }\end{array}$ \\
\hline
\end{tabular}

\footnotetext{
*。, after doxycycline administration. In follow up analyses performed after 12 months, the patient was free of skin and systemic disease without detection of $C$. pneumoniae in PBMCs; ${ }^{\circ}$, incomplete remission after doxycycline administration; $`, 6$ COP courses, cyclophosphamide, vincristine, prednisone. Remission, then recurrence of disease; ${ }^{\wedge}$, with doxycycline, then clarithromycin and quinolones administration.
} 


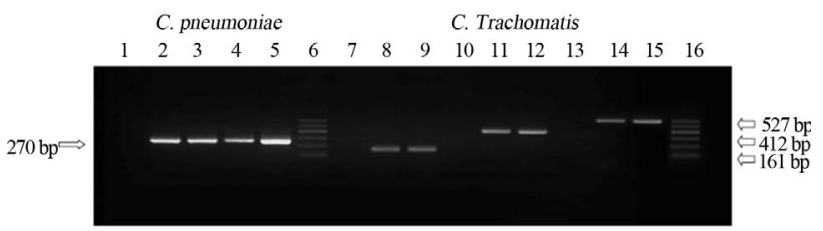

Figure 2. Chlamydia Spp. DNA detected in patient's specimen by PCR. Lanes 2 - 4: Positive product (270 bp) corresponding to 16s rRNA $C$. pneumoniae gene, from patients $n$. 2, 3, 4 (see Table 2); lanes 8, 11, 14: PCR positive products of $161 \mathrm{bp}, 412 \mathrm{bp}$ and $527 \mathrm{bp}$ corresponding to $C$. trachomatis HsP-60 604 portion, 16s rRNA and ompA/Momp genes were detected in specimen from patient $n .5$ (see Table 2). Amplification controls include negative (lane 1: C.p negative; lanes 7, 10 and 13: C.t negative) and positive controls (lane 5: C.p positive; lanes 9, 12 and 15: C.t positive corresponding, respectively, to DNA extracted from $C$. pneumoniae TW183 strain and $C$. trachomatis TW3 strain). Lanes 6 and 16: Marker $100 \mathrm{bp}$.

he achieved a complete lymphoma remission after CHOP cycles (cyclophosphamide, doxorubicin, vincristine, prednisone), Rituximab and COMP (cyclophosphamide, liposomal doxorubicin, vincristine, and prednisone), ended in April 2009. Due to recurrence of lymphoma (March 2012) and evidence of $C$. pneumoniae DNA, antibiotic therapy was given with partial remission.

Patient n. 1 was 66 years old and did not harbored bacterial DNA in both biopsy specimen and PBMCs.

Antibiotic therapy was not administered. In this case lymphoma remained stable and did not evolve.

No symptomatic toxicity or changes in biochemical parameters (serum levels of markers of hepatic and renal function) were observed in any patient sunder gone antibiotics.

The patient $\mathrm{n}$. 5 was a 53-year old Italian woman suffering from chronic HBV hepatitis. She had an indolent natural history of bilateral OAL in absence of lymph node enlargement and tissue involvement at total body CT scan. However, microscopic and immunocytochemical analysis of osteomedullary biopsy and the flow cytometry analysis of bone marrow cells obtained from a bone marrow aspirate, documented $12 \%$ neoplastic cells of clonal origin. The multicolour flow cytometry analysis excluded the presence of tumor cells in the peripheral blood. The patient underwent chemotherapy, which led to a complete disappearance of clonal lymphoid cells.

Because of the possible link between OAL and Chlamydia infection, she was investigated for Chlamydiae spp. and other pathogens including Mycoplasma and Ureaplasma urealyticum which proved all negative. Synovial fluid cultures as well as urogenital swabs for detecting $C$. trachomatis did not grow inclusion bodies. Screening for C. trachomatis was negative. The patient never had urogenital symptoms.

The above molecular and cultural techniques detected
C. trachomatis $16 \mathrm{~S}$ rRNA, OmpA, together with different Hsp-60 encoding genes, in both fresh lymphoma lesion and PBMC specimens co-cultured in optimized Hep-2 cell lines [68,101,102]. In particular, positive products of $412 \mathrm{bp}$ and $527 \mathrm{bp}$ corresponding to C. trachomatis 16S rRNA and OmpA gene, respectively, and three HsP-60-encoding genes [Ct-110, Ct-604, Ct-755] corresponding to $114-161 \mathrm{bp}$ were detected by PCR and RT-PCR in both clinical specimens as shown in Figure 2. The sequencing of PCR products detected a strict homology with C. trachomatis, as shown by BLAST analysis.

The patient was given doxycycline at same dosage for 4 weeks, which was safe and well tolerated, without receiving any concomitant therapy.

C. trachomatis PCR DNA and mRNA transcripts were negative in PBMCs after the conclusion of antibiotic treatment and a significant reduction of the ocularlesions was observed. $C$. trachomatis eradication was monitored at molecular level by assessing patient's PBMCs by laboratory investigators 6 months later and after 9 months of follow-up.

At 12-month from doxycycline assumption, C. trachomatis was no longer detectable in the patient's PBMCs. Ultrasonography was negative. One year after, the patient relapsed and a new ocular biopsy did detect OAL characterized by an indolent lesion with salmon red patch appearance in the bulbar conjunctiva of the right eye. Histological diagnosis was again a marginal zone B-cell lymphoma of MALT-type. PCR identified once more all three genes products associated to Hsp-60 gene in absence of 16S rRNA and ompA gene, whereas RT-PCR revealed an amplification signal corresponding only to the single Ct-604 portion of Hsp-60cDNA which continued to be positive after the suspension of doxycycline, in absence of OAL (Figure 2).

Doxycycline was again re-administered and a marked reduction of the eye lesionwas observed. A new evaluation of patient's PBMCs 1 month after starting therapydid detect again the identical molecular profile. Thus, we decided to administer an antibiotic regimen based onclarithromycin plus levofloxacin for 1 month. Tolerability and response were assessed by physical examination, blood sampling and imaging. The tolerability was excellent. The PBMC RT-PCR was negative for Hsp-60 gene in absence of DNA and at a distance of about 2 and half years from the lymphomatous manifestations, the patient has no complaints and molecular tests are negative in PBMCs. Ultrasound examinations and CT scans of the eye continue to be also negative.

\section{Therapeutic Strategies in OAL}

To date a critical topic is the lack of consensus about the best treatment for OAMZL disorders. Ideally, the opti- 
mal treatment should not be negatively counter balanced by side effects. In deciding of optimal therapy several factors must be taken into account and include: 1) histopathological type of lymphoma according to the WHO classification [103]; 2) extension of disease, within and outside the periocular region; 3) prognostic factors related to the patient [age, autoimmune disorders] and the disease; and 4) additionally consideration of the functional impact of the treatment on the eye $[19,104]$.

Several standard treatment modalities are available for OAL, including surgical excision and wait-and-see policy, radiotherapy and chemotherapy using single agent or combination regimens $[31,92,105]$. Advances in the knowledge of the immunophenotypic and genetic alterations in lymphoma cell lines have also led to a better understanding of the pathogenesis of the disease. In this regard, newer options such immunotherapy using interferon a and rituximab monoclonal (anti-CD20 antibody) and radioimmunotherapy, have been recently proposed although tested in small studies [92,105-107].

One of the most intriguing therapeutic approaches in recent times has been the use of tetracycline (doxycycline) for chlamydia-associated lymphomas.

The eradication of $C$. psittaci infection with doxycycline has been proposed as a fast, cheap, safe and active therapeutic option in patients with OAML and a valid alternative even in patients with multiple failures, involving previously irradiated areas or regional lymphadenopathies [78,109]. In this setting however, after the first encouraging results obtained in the treatment of OAL associated with $C$. psittaci, there have not always been satisfying and convincing confirmations in other studies $[108,109]$. This because of scarce reproducibility, short duration of the positive effect of the antibiotic onto proliferation of lymphoma [109,110], and achievement of a clinical response also in C. psittaci DNA negative cases [13]. The fact that even C. psittaci-negative lesions regressed with treatment, has led to hypothesize that other undiscovered doxycycline-sensitive organisms could also be involved in the pathogenesis of the OAL disease.

Varied results of treatment with antibiotics might be attributable also to the wide geographical variation in the prevalence of $C$. psittaci infection in OAL of MALT lymphoma origin, different genetic background of the patients with MALT lymphomas, and also by their sensitivity to the antibiotics that were selected for treatment.

A diagnostic biopsy with immunophenotyping and genetic analysis to determine the grade of the lymphoma combined with molecular analysis to determine the presence of an infective agent is strongly recommended. General treatment with antibiotics however, should be discouraged unless there is proof of an infective agent. If Chlamydial infection is found, a trial of oral doxycycline is worthwhile.

\section{Discussion}

The high prevalence of $C$. psittaci in patients with OAL has suggested a potential role, although it has been documented an evident geographical variability and response to antibiotic treatment (possibly related to the different techniques employed), the lack of stratification of response rates on histological subtypes of OAL, the genetic and phenotypic differences of C. psittaci strains in different countries and the reduced time of follow-up of these patients. In addition, the regression of lymphoma after antibiotic administration was often observed in patients not harboring C. psittaci DNA, suggesting that other undiscovered doxycycline-sensitive organisms may also be involved in the pathogenesis of disease [110]. Finally, there is not enough knowledge about the either of isolation of strains that display resistance to recommended antibiotics or of mechanisms of possible resistance in isolates from patients failing treatment. For $C$. pneumoniae, the findings so far obtained are very limited not only for identification in OAL but also for the specific treatment with antibiotics.

The results achieved by us in this regard are also limited and the 3 positive cases observed at our Institution, although studied and monitored over time showed that the response to doxycycline was partial or incomplete in 2 patients. Of interest, in the patient with cutaneous anaplastic eyelid with concurrent demonstration of $C$. pneumoniae and HHV-8 infection in both lymphomatous tissue and PBMC, we observed a complete response to doxycycline and after two years, C. pneumoniae was no longer detectable. However, any consideration about the possible role of antibiotic therapy in treating the neoplasm cannot be drawn, since the antibiotic treatment was started when the tumor had been surgically excised. Studies of more patients would be required to clarify the role of pathogens in this cutaneous lymphoma development.

The molecular and cultural evidence of $C$. trachomatis demonstrated for the first time in a female patient with OAL, seems to suggest that also this pathogen may contribute to pathogenesis of such lymphoma $[66,99]$.

In this case however, doxycycline was eradicating at initial diagnosis but not at relapse, as previously demonstrated [78].

Although clinical studies on the employment of macrolides alone or in association have not been largely performed, these compounds could be effectively employed in clinical settings when doxycycline doesn't work as expected. In this setting, a promising unconventional therapeutic approach derived by a 6 -month oral administration of clarithromycin, which has been tested in a Phase II trial including 12 patients with relapsed/refractory OAMZL; notably, the majority of these patients were previously treated with doxycycline. Clarithromycin has been successful in obtaining a 38\% clinical re- 
sponse rate in these patients, and in particular in those with conjunctival disease [111], suggesting that oral clarithromycin is safe and active in EMZL.

The rationale for the use of macrolide clarithromycin is that this drug is among the first line agents for the treatment of uncomplicated genital infections by C. trachomatis other than tetracyclines, quinolones and penicillins. Clarithromycin has also shown to induce apoptotic changes in tumor cells and to exhibit antitumor activity in murine cancer models and also in patients with MZL of the gastrointestinal tract [112].

Conversely, ciprofloxacin and ofloxacin have shown to be not eradicating the organism from host cells in vitro, but rather to induce a state of Chlamydia persistence characterized by the presence of noncultivable, but fully viable bacteria and the development of aberrant inclusions [9]. Despite this, however, the association of both compounds has been effective in eradicating $C$. trachomatis Hsp-60 cDNA in clinical specimens as demonstrated by RT-PCR [99].

\section{Conclusions}

The pathophysiological processes and molecular mechanisms that lead to the development of chronic inflammatory disease, persistence, and ultimately cancer, still need to be clarified. Future studies on a larger number of cases, longer follow-up time and above all, the use of a panel of techniques directed to detection of both Chlamydia DNA and mRNA transcripts in both blood and tissue specimens, combined with appropriate cell culture assay based on additional centrifugation and extension of culture time, would be useful not only for screening and diagnosis but also for monitoring genes related to bacterial persistence and to assess the effectiveness of therapy in these patients.

The potential application of bacteria-eradicating therapy at local and systemic level may ultimately result in safer and more efficient therapeutic option for patients affected by these malignancies. In this setting, the use of antibiotics in combination with immunomodulatory or cytostatic agents deserves to be investigated in future trials on EMZL and other lymphomas. In any case, a close collaboration between experts in ophthalmology, infectious diseases and hematology will help, in the future, to effectively manage this disease.

\section{REFERENCES}

[1] C. E. Margo and Z. D. Mulla, "Malignant Tumours of the Orbit: Analysis of the Floridacancer Registry," Ophthalmology, Vol. 105, No. 1, 1998, pp. 185-190. doi:10.1016/S0161-6420(98)92107-8

[2] K. Sasai, H. Yamabe, Y. Dodo, et al., "Non-Hodgkin's Lymphoma of the Ocular Adnexa," Acta Oncologica, Vol.
40, No. 4, 2001, pp. 485-90. doi: $10.1080 / 028418601750288217$

[3] J. I. Wyatt and B. J. Rathbone, "Immune Response of the Gastric Mucosa to Campylobacter pylori," Scandinavian Journal of Gastroenterology, Vol. 23, No. s142, 1988, pp. 44-49. doi:10.3109/00365528809091712

[4] V. Conteduca, D. Sansonno, G. Lauletta, S. Russi, G. Ingravallo and F. Dammacco, "H. pylori Infection and Gastric Cancer: State of the Art," International Journal of Oncology, Vol. 42, No. 1, 2013, pp. 5-18. doi:10.3892/ijo.2012.1701

[5] U. Dutta, P. K. Garg, R. Kumar and R. K. Tandon, "Typhoid Carriers among Patients with Gallstones Are at Increased Risk for Carcinoma of the Gallbladder," The American Journal of Gastroenterology, Vol. 95, No. 3, 2000, pp. 784-787. doi:10.1111/j.1572-0241.2000.01860.x

[6] L. Johnson, E. Wirotsko, W. Wirotsko, et al., "Mycoplasma-Like Organisms in Hodkin's Disease," The Lancet, Vol. 347, No. 9005, 1996, pp. 901-902. doi:10.1016/S0140-6736(96)91381-1

[7] D. N. Slater, "Borreliaburgdorferi-Associated Primary Cutaneous B-Cell Lymphoma," Histopathology, Vol. 38, No. 1, 2001, pp. 73-77. doi:10.1046/j.1365-2559.2001.01041.x

[8] A. J. Ferreri, M. Guidoboni, M. Ponzoni, et al., "Evidence for an Association between Chlamydia psittaci and Ocular Adnexal Lymphoma," Journal of the National Cancer Institute, Vol. 96, No. 8, 2004, pp. 586-594. doi:10.1093/jnci/djh102

[9] U. Dreses-Werringloer, I. Padubrin, B. Jürgens-Saathoff, et al., "Persistence of Chlamydia trachomatis Is Induced by Ciprofloxacin and Ofloxacin in Vitro," Antimicrobial Agents and Chemotherapy, Vol. 44, No. 12, 2000, pp. 3288-3297.

[10] A. Husain, D. Roberts, B. Pro, et al., "Meta-Analyses of the Association between Chlamydia psittaci and Ocular Adnexal Lymphoma and the Response of Ocular Adnexal Lymphoma to Antibiotics," Cancer, Vol. 110, No. 4, 2007, pp. 809-815. doi:10.1002/cncr.22843

[11] C. Jenkins, G. E. Rose, C. Bunce, et al., "Histological Features of Ocular Adnexal Lymphoma (REAL Classification) and Their Association with Patient Morbidity and Survival," British Journal of Ophthalmology, Vol. 84, No. 8, 2000, pp. 907-913. doi:10.1136/bjo.84.8.907

[12] P. G. Isaacson and M.-Q. Du, "MALT Lymphoma: From Morphology to Molecules," Nature Reviews Cancer, Vol. 4, No. 8, 2004, pp. 644-653. doi:10.1038/nrc1409

[13] M. Guidoboni, A.J. Ferreri, M. Ponzoni, et al., "Infectious Agents in Mucosa-Associated Lymphoid Tissue-Type Lymphomas: Pathogenic Role and Therapeutic Perspectives," Clinical Lymphoma and Myeloma, Vol. 6, No. 4, 2006, pp. 289-300. doi:10.3816/CLM.2006.n.003

[14] K. Tanimoto, A. Kaneko, S. Suzuki, et al., "Primary Ocular Adnexal MALT Lymphoma: A Long-Term Follow-Up Study of 114 Patients," Japanese Journal of Clinical Oncology, Vol. 37, No. 5, 2007, pp. 337-344.

[15] J. Meunier, L. L.-L. Rouic, A. Vincent-Salomon, et al., "Ophthalmologic and Intraocular Non-Hodgkin's Lym- 
phoma: A Large Single Centre Study of Initial Characteristics, Natural History, and Prognostic Factors," Hematological Oncology, Vol. 22, No. 4, 2004, pp. 143-158. doi:10.1002/hon.741

[16] E. Y. Cho, J. J. Han, H. J. Ree, et al., "Clinicopathologic Analysis of Ocular Adnexal Lymphomas: Extranodal Marginal Zone B-Cell Lymphoma Constitutes the Vast Majority of Ocular Lymphomas among Koreans and Affects Younger Patients," American Journal of Hematoogyl, Vol. 73, No. 2, 2003, pp. 87-96. doi:10.1002/ajh.10332

[17] R. Moslehi, S. S. Devesa, C. Schairer and J. F. Fraumeni Jr., "Rapidly Increasing Incidence of Ocular Non-Hodgkin Lymphoma," Journal of the National Cancer Institute, Vol. 98, No. 11, 2006, pp. 936-939. doi:10.1093/jnci/dji248

[18] A. J. Ferreri, R. Dolcetti, S. Magnino, et al., "Chlamydial Infection: The Link with Ocular Adnexal Lymphomas," Nature Reviews Clinical Oncology, Vol. 6, No. 11, 2009, pp. 658-669.

[19] D. Decaudin, P. de Cremoux, A. Vincent-Salomon, et al., "Ocular Adnexal Lymphoma: A Review of Clinicopathologic Features and Treatment Options," Blood, Vol. 108, No. 5, 2006, pp. 1451-1460. doi:10.1182/blood-2006-02-005017

[20] V. Verma, D. Shen, P. C. Sieving, et al., "The Role of Infectious Agents in the Etiology of Ocular Adnexal Neoplasia," Survey of Ophthalmology, Vol. 53, No. 4, 2008, pp. 312-331.

doi:10.1016/j.survophthal.2008.04.008

[21] S. Bhatia, A. C. Paulino, J. M. Buatti, et al., "Curative Radiotherapy for Primary Orbital Lymphoma," International Journal of Radiation Oncology*Biology*Physics, Vol. 54, No. 3, 2002, pp. 818-23. doi:10.1016/S0360-3016(02)02966-8

[22] S. Martinet, M. Ozsahin, Y. Belkacémi, et al., "Outcome and Prognostic Factors in Orbital Lymphoma: A Rare Cancer Network Study on 90 Consecutive Patients Treated with Radiotherapy Mar," International Journal of Radiation Oncology*Biology*Physics, Vol. 55, No. 4, 2003, pp. 892-898. doi:10.1016/S0360-3016(02)04159-7

[23] T. Uno, K. Isobe, N. Shikama, et al., "Radiotherapy for Extranodal, Marginal Zone, B-Cell Lymphoma of $\mathrm{Mu}-$ cosa-Associated Lymphoid Tissue Originating in the Ocular Adnexa: A Multiinstitutional, Retrospective Review of 50 Patients," Cancer, Vol. 98, No. 4, 2003, pp. 865-871. doi:10.1002/cncr.11539

[24] F. Collina, A. De Chiara, A. De Renzo, et al., "Chlamydia psittaci in Ocular Adnexa MALT Lymphoma: A Possible Role in Lymphomagenesis and a Different Geographical Distribution," Infectious Agents and Cancer, Vol. 7, No. 8, 2012. doi:10.1186/1750-9378-7-8

[25] A. J. Ferreri, A. Assanelli, R. Crocchiolo, et al., "Therapeutic Management of Ocular Adnexal MALT Lymphoma," Expert Opinion on Pharmacotherapy, Vol. 8, No. 8, 2007, pp. 1073-1083. doi:10.1517/14656566.8.8.1073

[26] B. Streubel, I. Simonitsch-Klupp, L. Müllauer, et al., "Variable Frequencies of MALT Lymphoma-Associated Genetic Aberrations in MALT Lymphomas of Different
Sites," Leucemia, Vol. 18, No. 10, 2004, pp. 1722-1726.

[27] H. Inagaki, "Mucosa-Associated Lymphoid Tissue Lymphoma: Molecular Pathogenesis and Clinicopathological Significance," Pathology International, Vol. 57, No. 8, 2007, pp. 474-484.

[28] P. C. Lucas, M. Yonezumi, N. Inohara, et al., "Bc110 and MALT1, Independent Targets of Chromosomal Translocation in MALT Lymphoma, Cooperate in a Novel NF-B Signalling Pathway," Journal of Biology and Chemistry, Vol. 276, No. 22, 2001, pp. 19012-19019. doi:10.1074/jbc.M009984200

[29] U. Novak, A. Rinaldi, I. Kwee, et al., "The NF-\{kappa $\}$ B Negative Regulator TNFAIP3 (A20) Is Inactivated by Somatic Mutations and Genomic Deletions in Marginal Zone Lymphomas," Blood, Vol. 113, No. 20, 2009, pp. 4918-4921. doi:10.1182/blood-2008-08-174110

[30] K. Honma, S. Tsuzuki, M. Nakagawa et al., "TNF-AIP3 Is the Target Gene of Chromosome Band 6q23.3-q24.1 Loss in Ocular Adnexal Marginal Zone B Cell Lymphoma," Genes Chromosomes and Cancer, Vol. 47, No. 1, 2008, pp. 1-7. doi:10.1002/gcc.20499

[31] P. A. McKelvie, "Ocular Adnexal Lymphomas: A Review," Advance in Anatomic Pathology, Vol. 17, No. 4, 2010, pp. 251-261. doi:10.1097/PAP.0b013e3181e4abdb

[32] K. D. Everett, R. M. Bush and A. A. Andersen, "Emended Description of the Order Chlamydiales, Proposal of Parachlamydiaceae fam. nov. and Simkaniaceae fam. nov., Each Containing Onemonotypic Genus, Revised Taxonomy of the Family Chlamydiaceae, Including A New Genus and Five New Species, and Standards for the Identification of Organisms," International Journal of Systematic and Evolutionary Microbiology, Vol. 49, No. 2, 1999, pp. 415-440. doi:10.1099/00207713-49-2-415

[33] A. Dautry-Varsat, A. Subtil and T. Hackstadt, "Recent Insights into the Mechanisms of Chlamydia Entry," Celularl Microbiology, Vol. 7, No. 12, 2005, pp. 1714-1722.

[34] F. N. Wuppermann, K. Mölleken, M. Julien, et al., "Chlamydia pneumonia GroEL1 Protein Is Cell Surface Associated and Required for Infection of HEp-2 Cells," Journal of Bacteriology, Vol. 190, No. 10, 2008, pp. 37573767. doi:10.1128/JB.01638-07

[35] J. W. Moulder, "Interaction of Chlamydiae and Host Cells in Vitro," Microbiological Reviews, Vol. 55, No. 1, 1991, pp. 143-190.

[36] H. C. Gérard, B. Krausse-Opatz, Z. Wang, et al., "Expression of Chlamydia trachomatis Genes Encoding Products Required for DNA Synthesis and Cell Division during Active versus Persistent Infection," Molecular Microbiology, Vol. 41, No. 3, 2001, pp. 731-741. doi:10.1046/j.1365-2958.2001.02550.x

[37] R. S. Stephens, "The Cellular Paradigm of Chlamydial Pathogenesis," Trends in Microbiology, Vol. 11, No. 1, 2003, pp. 44-51. doi:10.1016/S0966-842X(02)00011-2

[38] R. J. Hogan, S. A, Mathews, S. Mukhopadhyay, et al., "Chlamydial Persistence: Beyond the Biphasic Paradigm," Infection and Immunity, Vol. 72, No. 4, 2004, pp. 18431855. doi:10.1128/IAI.72.4.1843-1855.2004

[39] A. Kutlin, C. Flegg, D. Stenzel, et al., "Ultrastructural 
Study of Chlamdyia pneumoniae in a Continuous-Infection Model," Journal of Clinical Microbiology, Vol. 39, No. 10, 2001, pp. 3721-3723. doi:10.1128/JCM.39.10.3721-3723.2001

[40] D. Dean and W. C. Powers, "Persistent Chlamydia trachomatis Infections Resist Apoptotic Stimuli," Infection and Immunity, Vol. 69, No. 4, pp. 2442-2447.

[41] W. L. Beatty, R. P. Morrison and G. I. Byrne, "Persistent Chlamydiae: From Cell Culture to a Paradigm for Chlamydial Pathogenesis," Microbiological Reviews, Vol. 58, No. 4, 1994, pp. 686-699.

[42] J. E. Raulston, "Response of Chlamydia trachomatis Serovar E to Iron Restriction in Vitro and Evidence for Iron-Regulated Chlamydial Proteins," Infection and Immunity, Vol. 65, No. 11, 1997, pp. 4539-4547.

[43] E. A. Sueltenfuss and M. Pollard, "Cytochemical Assay of Interferon Produced by Duck Hepatitis Virus," Science, Vol. 139, No. 3555, 1963, pp. 595-596. doi:10.1126/science.139.3555.595

[44] L. M. Sardinia, E. Segal and D. Ganem, "Developmental Regulation of the Cysteine-Rich Outermembrane Proteins of Murine Chlamydia trachomatis," Journal of General Microbiology, Vol. 134, No. 4, 1988, pp. 997-1004.

[45] S. Bas, L. Neff, M. Vuillet, et al., "The Proinflammatory Cytokine Response to Chlamydia trachomatis Elementary Bodies in Human Macrophages Is Partly Mediated by A Lipoprotein, the Macrophage Infectivity Potentiator, through TLR2/TLR1/TLR6 and CD14," The Journal of Immunology, Vol. 180, No. 2, 2008, pp. 1158-1168.

[46] Y. Naiki, K. S. Michelsen, N. W. Schröder, et al., "MyD88 Is Pivotal for the Early Inflammatory Response and Subsequent Bacterial Clearance and Survival in a Mouse Model of Chlamydia pneumoniae Pneumonia," The Journal of Biological Chemistry, Vol. 280, No. 32, 2005, pp. 29242-29249. doi:10.1074/jbc.M503225200

[47] J. Peters, D. P. Wilson, G. Myers, et al., "Type III Secretion à la Chlamydia," Trends in Microbiology, Vol. 15, No. 6, 2007, pp. 241-251. doi:10.1016/j.tim.2007.04.005

[48] G. M. Zhong, "Killing Me Softly: Chlamydial Use of Proteolysis for Evading Host Defenses," Trends in Microbiology, Vol. 17, No. 10, 2009, pp. 467-474. doi:10.1016/i.tim.2009.07.007

[49] K. Manavi, "A Review on Infection with Chlamydia trachomatis," Best Practice \& Research Clinical Obstetrics \& Gynaecology, Vol. 20, No. 6, 2006, pp. 941-951. doi:10.1016/j.bpobgyn.2006.06.003

[50] J. Schachter, E. C. Hill, E. B. King, et al., "Chlamydial Infection in Women with Cervical Dysplasia," American Journal of Obstetrics and Gynecology, Vol. 123, No. 7, 1975 , pp. $753-757$

[51] J. T. Quirk and J. M. Kupinski, "Chronic Infection, Inflammation, and Epithelial Ovarian Cancer," Medical Hypotheses, Vol. 57, No. 4, 2001, pp. 426-428. doi:10.1054/mehy.2001.1326

[52] A. Olejek, I. Kozak-Darmas, S. Kellas-Sleczka, et al., "Chlamydia trachomatis Infection in Women with Lichen Sclerosus Vulvae and Vulvar Cancer," Neuro Endocrinology, Vol. 30, No. 5, 2009, pp. 671-674.
[53] K. L. Millman, S. Tavare, D. Dean, "Recombination in the OmpA Gene but Not the OmcB Gene of Chlamydia Contributes to Serovar-Specific Differences in Tissue Tropism, Immune Surveillance, and Persistence of the Organism," Journal of Bacteriology, Vol. 183, No. 20, 2001, pp. 5997-6008. doi:10.1128/JB.183.20.5997-6008.2001

[54] F. Cappello, F. C. de Macario, V. Di Felice, et al., "Chlamydia trachomatis Infection and Anti-Hsp60 Immunity: The Two Sides of the Coin," PLoS Pathogens, Vol. 5, No. 8, 2009, p. e1000552.

[55] M. Kauppinen and P. Saikku, "Pneumonia Due to Chlamydia Pneumoniae: Prevalence, Clinical Features, Diagnosis, and Treatment," Clinical Infectious Diseases, Vol. 21, Suppl. 3, 1995, pp. S244-S252. doi:10.1093/clind/21.Supplement 3.S244

[56] C. C. Kuo, L. A. Jackson, L. A. Campbell, et al., "Chlamydia pneumoniae (TWAR)," Clinical Microbiology Reviews, Vol. 8, No. 4, 1995, pp. 451-461.

[57] P. Saikku, M. Leinonen, K. Mattila, et al., "Serological Evidence of an Association of a Novel Chlamydia, TWAR, with Chronic Coronary Heart Disease and Acute Myocardial Infarction," The Lancet, Vol. 332, No. 8618, 1988, pp. 983-986. doi:10.1016/S0140-6736(88)90741-6

[58] M. S. Elkind, I. F. Lin, J. T. Grayston, et al., "Chlamydia pneumoniae and the Risk of First Ischemic Stroke: The Northern Manhattan Stroke Study," Stroke, Vol. 31, No. 7, 2000, pp. 1521-1525. doi:10.1161/01.STR.31.7.1521

[59] S. Sriram, A. Ljunggren-Rose, S. Y. Yao, et al., "Detection of Chlamydial Bodies and Antigens in the Central Nervous System of Patients with Multiple Sclerosis," The Journal of Infectious Diseases, Vol. 192, No. 7, 2005, pp. 1219-1228. doi:10.1086/431518

[60] C. Contini, R. Cultrera, S. Seraceni, et al., "Cerebrospinal Fluid Molecular Demonstration of Chlamydia pneumoniae DNA Is Associated to Clinical and Brain Magnetic Resonance Imaging Activity in a Subset of Patients with Relapsing-Remitting Multiple Sclerosis," Multiple Sclerosis Journal, Vol. 10, No. 4, 2004, pp. 360-369. doi:10.1191/1352458504ms1049oa

[61] C. Contini, S. Seraceni, et al., "Chlamydophila pneumoniae Infection and Its Role in Neurological Disorders," Interdisciplinary Perspectives Infectious Diseases, Vol. 2010, 2010, Article ID: 273573.

[62] A. K. Chaturvedi, C. A. Gaydos, P. Agreda, et al., "Chlamydia pneumoniae Infection and Risk for Lung Cancer," Cancer Epidemiology, Biomarkers \& Prevention, Vol. 19, No. 6, 2010, p. 1505. doi:10.1158/1055-9965.EPI-09-1261

[63] A. J. Littman, L. A. Jackson and T. L. Vaughan, "Chlamydia pneumoniae and Lung Cancer: Epidemiologic Evidence," Cancer Epidemiology Biomarkers \& Prevention, Vol. 14, No. 4, 2005, pp. 773-778. doi:10.1158/1055-9965.EPI-04-0599

[64] B. Kocazeybek, "Chronic Chlamydophila pneumoniae Infection in Lung Cancer, a Risk Factor: A Case-Control Study," Journal of Medical Microbiology, Vol. 52, No. 8, 2003, pp. 721-726. doi:10.1099/jmm.0.04845-0

[65] P. Zhan, L. J. Suo, Q. Qian, et al., "Chlamydia pneumo- 
niae Infection and Lung Cancer Risk: Meta-Analysis," European Journal of Cancer, Vol. 47, No. 5, 2011, pp. 742-747. doi:10.1016/j.ejca.2010.11.003

[66] C. Contini and S. Seraceni, "Chlamydial Disease: A Cross-Road between Chronic Infection and Development of Cancer," In: A. A. Khan, Bacteria and Cancer, Chapter 4, Springer Science, Berlin, 2012, pp. 79-116.

doi:10.1007/978-94-007-2585-0 4

[67] T. J. Bodetti, P. Timms, "Detection of Chlamydia pneumoniae DNA and Antigen in the Circulating Mononuclear Cell Fractions of Humans and Koalas," Infection and Immunity, Vol. 68, No. 5, 2000, 2744-2747. doi:10.1128/IAI.68.5.2744-2747.2000

[68] C. Contini, S. Seraceni, M. Castellazzi, et al., "Chlamydophila pneumoniae DNA and mRNA Transcript Levels in Peripheral Blood Mononuclear Cells and Cerebrospinal Fluid of Patients with Multiple Sclerosis," Neuroscience Research, Vol. 62, No. 1, 2008, pp. 58-61. doi:10.1016/i.neures.2008.05.003

[69] S. Haranaga, H. Yamaguchi, H. Friedman, et al., "Chlamydia pneumoniae Infects and Multiplies in Lymphocytes in Vitro," Infection and Immunity, Vol. 69, No. 12, 2001, pp. 7753-7759. doi:10.1128/IAI.69.12.7753-7759.2001

[70] G. Van Zandergen, J. Gieffers, H. Kothe, et al., "Chlamydia pneumoniae Multiply in Neutrophil Granulocytes and Delay Their Spontaneous Apoptosis," The Journal of Immunology, Vol. 172, No. 3, 2004, pp. 1768-1776.

[71] C. Yucesan and S. Sriram, "Chlamydia pneumoniae Infection of the Central Nervous System," Current OpinNeurology, Vol. 14, No. 3, 2001, pp. 355-359. doi:10.1097/00019052-200106000-00015

[72] L. Rasanen, M. Lehto, I. Jokinen, et al., "Polyclonal Antibody Formation of Human Lymphocytes to Bacterial Components," Immunology, Vol. 58, No. 4, 1986, pp. 577-581.

[73] G. I. Byrne and D. M. Ojcius, "Chlamydia and Apoptosis: Life and Death Decisions of an Intracellular Pathogen," Nature Reviews Microbiology, Vol. 2, No. 10, 2004, pp. 802-808. doi:10.1038/nrmicro1007

[74] L. Hanna, L. Schmidt, M. Sharp, et al., "Human CellMediated Immune Responses to Chlamydial Antigens," Infection and Immunity, Vol. 23, No. 2, 1979, pp. 412417.

[75] I. Miyairi and G. I. Byrne, "Chlamydia and Programmed Cell Death," Current Opinion in Microbiology, Vol. 9, No. 1, 2006, pp. 102-108. doi:10.1016/j.mib.2005.12.004

[76] A. Aigelsreiter, T. Gerlza, A. J. Deutsch, et al., "Chlamydia psittaci Infection in Nongastrointestinal Extranodal MALT Lymphomas and Their Precursor Lesions," American Society for Clinical Pathology, Vol. 135, No. 1, 2011, pp. 70-75. doi:10.1309/AJCPXMDRT1SY6KIV

[77] J. E. Sykes, G. A. Anderson, V. P. Studdert, et al., "Prevalence of Feline Chlamydia psittaci and Feline Herpesvirus 1 in Cats with Upper Respiratory Tract Disease," Journal of Veterinary Internal Medicine, Vol. 13, No. 3, 1999, pp. 153-162. doi:10.1111/j.1939-1676.1999.tb02172.x
[78] A. J. Ferreri, M. Ponzoni, M. Guidoboni, et al., "Regression of Ocular Adnexal Lymphoma after Chlamydia psittaci-Eradicating Antibiotic Therapy," Journal of Clinical Oncology, Vol. 23, No. 22, 2005, pp. 5067-5073. doi:10.1200/JCO.2005.07.083

[79] A. J. Ferreri, R. Dolcetti, G. P. Dognini, et al., "Chlamydophila psittaci Is Viable and Infectious in the Conjunctiva and Peripheral Blood of Patients with Ocular Adnexal Lymphoma: Results of a Single-Center Prospective Case-Control Study," International Journal of Cancer, Vol. 123, No. 5, 2008, pp. 1089-1093. doi:10.1002/ijc. 23596

[80] M. F. Rosado, G. E. Byrne Jr., F. Ding, et al., "Ocular Adnexal Lymphoma: A Clinicopathological Study of a Large Cohort of Patients with No Evidence for an Association with Chlamydia psittaci," Blood, Vol. 107, No. 2, 2006, pp. 467-472. doi:10.1182/blood-2005-06-2332

[81] M. Q. Du, "MALT Lymphoma: Recent Advances in Aetiology and Molecular Genetics," Journal of Clinical and Experimental Hematopathology, Vol. 47, No. 2, 2007, pp. 31-42. doi:10.3960/jslrt.47.31

[82] C. Yoo, M. H. Ryu, J. Huh, et al., "Chlamydia psittaci Infection and Clinicopathologic Analysis of Ocular Adnexal Lymphomas in Korea," American Journal of Hematology, Vol. 82, No. 9, 2007, pp. 821-823. doi:10.1002/ajh.20962

[83] M. Daibata, Y. Nemoto, K. Togitani, et al., "Absence of Chlamydia psittaci in Ocular Adnexal Lymphoma from Japanese Patients," British Journal of Haematology, Vol. 132, No. 5, 2006, pp. 651-652. doi:10.1111/j.1365-2141.2005.05943.x

[84] Y. C. Liu, J. H. Ohyashiki, Y. Ito, et al., "Chlamydia psittaci in Ocular Adnexal Lymphoma: Japanese Experience," Leukemia Research, Vol. 30, No. 12, 2006, pp. 1587-1589. doi:10.1016/j.leukres.2006.01.015

[85] M. M. Mulder, E. R. Heddema, Y. Pannekoek, et al., "No Evidence for an Association of Ocular Adnexal Lymphoma with Chlamydia psittaci in a Cohort of Patients from the Netherlands," Leukemia Research, Vol. 30, No. 10, 2006, pp. 1305-1307. doi:10.1016/j.leukres.2005.12.003

[86] E. Chanudet, Y. Zhou, C. M. Bacon, et al., "Chlamydia psittaci Is Variably Associated with Ocular Adnexal MALT Lymphoma in Different Geographical Regions," The Journal of Pathology, Vol. 209, No. 3, 2006, pp. 344-351. doi:10.1002/path.1984

[87] E. Gracia, P. Froesch, L. Mazzucchelli, et al., "Low Prevalence of Chlamydia psittaci in Ocular Adnexal Lymphomas from Cuban Patients," Leukemia \& Lymphoma, Vol. 48, No. 1, 2007, pp. 104-108. doi:10.1080/10428190600908174

[88] A. Carugi, A. Onnis, G. Antonicelli, et al., "Geographic Variation and Environmental Conditions as Cofactors in Chlamydia psittaci Association with Ocular Adnexal Lymphomas: A Comparison between Italian and African Samples," Hematological Oncology, Vol. 28, 2010, pp. 20-26.

[89] R. L. Vargas, E. Fallone, R. E. Felgar, et al., "Is There an Association between Ocular Adnexal Lymphoma and In- 
fection with Chlamydia psittaci? The University of Rochester Experience," Leukemia Research, Vol. 30, No. 5, 2006, pp. 547-551. doi:10.1016/j.leukres.2005.09.012

[90] M. Ponzoni, A. J. Ferreri, M. Guidoboni, et al., "Chlamydia Infection and Lymphomas: Association beyond Ocular Adnexal Lymphomas Highlighted by Multiple Detection Methods," Clinical Cancer Research, Vol. 14, No. 18,2008 , pp. 5794-5800. doi:10.1158/1078-0432.CCR-08-0676

[91] G. Madico, T. C. Quinn, J. Boman, et al., "Touchdown Enzyme Time Release-PCR for Detection and Identification of Chlamydia trachomatis, C. pneumoniae, and $C$. psittaci Using the 16S and 16S-23S Spacer rRNA Genes," Journal of Clinical Microbiology, Vol. 38, No. 3, 2000, pp. 1085-1093.

[92] M. Ponzoni, A. J. Ferreri, C. Dogliosi, et al., "Unconventional Therapies in Ocular Adnexal Lymphomas," Expert Review of Anticancer Therapy, Vol. 10, No. 9, 2010, pp. 1341-1343. doi:10.1586/era.10.125

[93] D. Shen, H. K. Yuen, D. A. Galita, et al., "Detection of Chlamydia pneumoniae in a Bilateral Orbital MucosaAssociated Lymphoid Tissue Lymphoma," American Journal of Ophthalmology, Vol. 141, No. 6, 2006, pp. 11621163. doi:10.1016/j.ajo.2006.01.067

[94] C. C. Chan, D. Shen, M. Mochizuki, et al., "Detection of Helicobacter pylori and Chlamydia pneumoniae Genes in Primary Orbital Lymphoma," Transactions of American Ophthalmological Society, Vol. 104, 2006, pp. 62-70.

[95] Centers for Disease Control and Prevention, "Sexually Transmitted Diseases Surveillance," http://www.cdc.gov/std/stats11/chlamydia.htm

[96] J. Schachter, "Infection and Disease Epidemiology," In: R. S. Stephens, Ed., Chlamydia: Intracellular Biology, Pathogenesis and Immunity, ASM Press, Washington DC, 1999, pp. 139-169.

[97] H. C. Gérard, J. A. Whittum-Hudson, J. D. Carter and A. P. Hudson, "Molecular Biology of Infectious Agents in Chronic Arthritis," Rheumatic Disease Clinics of North America, Vol. 35, No. 1, 2009, pp. 1-19. doi:10.1016/j.rdc.2009.03.011

[98] R. V. Schoborg, "Chlamydia Persistence-A Tool to Dissect Chlamydia-Host Interactions," Microbes and Infection, Vol. 13, No. 7, 2011, pp. 649-662. doi:10.1016/j.micinf.2011.03.004

[99] C. Contini, S. Seraceni, S. Carradori, et al., "Identification of Chlamydia trachomatis in a Patient with Ocular Lymphoma," American Journal of Hematology, Vol. 84, No. 9, 2009, pp. 597-599. doi:10.1002/ajh.21477

[100] C. Contini, E. Caselli, A. Borghi, et al., "Evidence of Chlamydophila pneumoniae and Human Herpesvirus 8 in Primary Cutaneous Anaplastic Large-Cell Lymphoma," 23rd ECCMID, Berlin, 27-30 April 2013, Abstract N. 2255.
[101] H. C. Gerard, J. A. Whittum-Hudson, H. R. Schumacher et al., "Differential Expression of Three Chlamydia trachomatis Hsp60-Encoding Genes in Active vs. Persistentinfections," Microbial Pathogenesis, Vol. 36, No. 1, 2004, 35-39. doi:10.1016/j.micpath.2003.08.005

[102] J. M. Pruckler, N. Masse, V. A. Stevens, et al., "Optimizing Culture of Chlamydia pneumonia by Using Multiple Centrifugations," Journal of Clinical Microbiology, Vol. 37, No. 10, 1999, pp. 3399-3401.

[103] S. H. Swerdlow, E. Campo and N. L. Harris, "The WHO Classification of Tumours of the Haemopoietic and Lymphoid Tissues," IARC Press, Lyon, 2008.

[104] A. J. Ferreri, R. Dolcetti, M. Q. Due, et al., "Ocular Adnexal MALT Lymphoma: An Intriguing Model for Antigen-Driven Lymphomagenesis and Microbial Targeted Therapy," Annals of Oncology, Vol. 19, No. 5, 2007, pp. 835-846. doi:10.1093/annonc/mdm513

[105] V. M. Cohen, "Treatment Options for Ocular Adnexal Lymphoma (OAL)," Clinical Ophthalmology, Vol. 3, No. 2009, 2009, pp. 689-692.

[106] C. Heinz, H. Merz, M. Nieschalk, et al., "Rituximab for the Treatment of Extranodal Marginal Zone B-Cell Lymphoma of the Lacrimal Gland," British Journal of Ophthalmology, Vol. 91, No. 11, 2007, pp. 1563-1564. doi:10.1136/bjo.2007.115626

[107] B. Esmaeli, P. McLaughlin, B. Pro, et al., "Prospective Trial of Targeted Radioimmunotherapy with Y-90 Ibritumomabtiuxetan (Zevalin) for Front-Line Treatment of Early-Stage Extranodal Indolent Ocular Adnexal Lymphoma," Annals of Oncology, Vol. 20, No. 4, 2009, pp. 709-714. doi:10.1093/annonc/mdn692

[108] B. Grünberger, W. Hauff, J. Lukas, et al., “ 'Blind' Antibiotic Treatment Targeting Chlamydia Is Not Effective in Patients with MALT Lymphoma of the Ocular Adnexa," Annals of Oncology, Vol. 17, No. 3, 2006, pp. 484-487.

[109] A. J. Ferreri, M. Ponzoni, M. Guidoboni, et al., "Bacteria-Eradicating Therapy with Doxycycline in Ocular Adnexal MALT Lymphoma: A Multicenter Prospective Trial," Journal of the national institute, Vol. 98, No. 19, 2006, pp. 1375-1382. doi:10.1093/jnci/djj373

[110] J. M. Matthews, L. I. Moreno and J. Dennis, "Ocular Adnexal Lymphoma: No Evidence for Bacterial DNA Associated with Lymphoma Pathogenesis," British Journal of Haematology, Vol. 142, No. 2, 2008, pp. 246-249. doi:10.1111/j.1365-2141.2008.07112.x

[111] S. Govi, R. Dolcetti, M. Ponzoni, et al., “A Phase II Trial to Investigate the Link with Infectious Agents in Ocular Adnexal Marginal Zone Lymphoma, Especially with Chlamydia Species, and the Antineoplastic Effects of Doxycycline," Haematologica, Vol. 95, Suppl. 2, 2010, p. 282.

[112] T. Matsumoto and M. Iida, "Extra-Gastric Lymphoma of MALT Type and H. pylori Eradication," Nippon Rinsho, Vol. 63, Suppl. 1, 2005, pp. 308-311. 